\title{
Job Hopping Behavior among Coffee Shops Employees in Malaysia
}

\author{
Hazrina Ghazali (Corresponding author) \\ Department of Food Service and Management, Faculty of Food Science and Technology \\ University Putra Malaysia 43400 Serdang, Selangor, Malaysia
}

\section{Zulaikha Hizreen Hashim}

Department of Food Service and Management, Faculty of Food Science and Technology

University Putra Malaysia 43400 Serdang, Selangor, Malaysia

\begin{abstract}
Maisarah Ishak
Faculty of Business and Management, Universiti Teknologi MARA Pahang, Jengka Campus, 26400 Bandar Tun Abdul Razak Jengka, Pahang Malaysia
\end{abstract}

Received: Jun. 29, $2021 \quad$ Accepted: Aug. 9, 2021 Online published: Aug. 20, 2021

doi:10.5296/ijhrs.v11i3.18818ＵRL: https://doi.org/10.5296/ijhrs.v11i3.18818

\begin{abstract}
Job hopping behavior may have an adverse effect on both employers and employees. For the perspective of employee, there are many factors might influence an employee's decision to job hop including salary dissatisfaction or a better offer elsewhere. The issue of job hopping has been a serious concern for many organizations, and the coffee shops industry is no exception. Therefore, the goal of this research is to discover potential factors influencing to job hopping behavior among coffee shops employees, as well as the relationship of identified factors with job hopping. Job satisfaction, financial and perceived organizational support were the three factors investigated in this research. A total of 231 questionnaires were distributed to employees who are currently working in the coffee shops in Klang Valley area and 215 usable responses returned for a response rate of 93.1 percent. The collected data was analyzed by using Statistical Package for Social Sciences (SPSS) latest version. Results of the job satisfaction (mean= 3.5636), financial $(m=3.5622)$ and perceived organization support $($ mean $=3.5601)$ shows score lean towards agreement level. Additionally, findings showed that
\end{abstract}


the correlation of all the variables were weak correlated. A multiple regression also was run to predict job hopping behaviour with the three independent variables. Results found that only $6.9 \%$ of variance in coffee shops' employees was explained by job satisfaction, financial and perceived organization support $\left(\mathrm{R}^{2}=.069\right)$. Even though the findings of this research found that these three variables did not have a direct impact on coffee shop employees' decision to job hop, the findings may provide some guidance and alert coffee shop owners or managers to the importance of these three variables in the coffee shops industry in order to minimize job hopping and will be discussed further in this paper.

Keywords: job hopping behavior, job satisfaction, financial, perceived organization support, coffee shop, Klang Valley, Malaysia

\section{Introduction}

Hiring, preserving, and managing human capital are top priorities in today's human resources sector. Employees' increasing expectations of higher salaries and benefits, job patterns, job security, the importance of their role, and decision-making attitudes often lead them to consider hopping from one place to another (Ghazali \& Roslan, 2020). For example, in previous research found that 83 percent of Malaysian employees preferred a better pay as the primary reason for changing jobs (Human Resources Online, 2018). Apart from salary being a major element in job hopping, job hoppers are also known to switch jobs frequently (29\%) due to a lack of advancement chances in their current industry (Human Resources Online, 2018).

A job hopper is known as a person that change the job frequently and prefers to work in a single position for a short period rather than staying with the same company for many years. It commonly describe as employees who are migrating from their current job and there are many reasons contributed to job hopping behavior such as salary dissatisfaction, availability of job choices in the market, career advancement, and perfect job fit, gaining more skills or opportunities as well as work-life balance (Ghazali, Jules \& Othman, 2018, Ramkumar, et al. 2016). Job hoppers also known as a person who cannot remain in an organization and also do not interested in their current jobs.

Furthermore, the issues of job hopping becoming a major problem to the business failure due to losing the talent of expertise and technical abilities that left the organization and affect the productivity, quality, and profitability of the organization. When the most skillful, knowledgeable and talent employees job hop and left the organization for some reason and there will be less talent to stay in the organization. It is agreed that job hopping behavior puts pressure on managers to keep their best employees. It is essential to take measures to prevent job hopping before it happened. Therefore, this study aimed to understand and identify possible reasons of job hopping and its relationship among employees of coffee shop industry especially in Klang Valley area, Malaysia. The specific objectives of the study are:

1. To identify possible factors influence job hopping behavior among employees in coffee shops industry 
2. To examine relationship between factors influence and job hopping behavior among employees in coffee shops industry

3. To predict factors that influenced job hopping behavior among employees in coffee shops industry

\section{Literature Review}

\section{Definition of Job Hopping}

Currently, an employee's job hopping is a very serious issue that often happened in an organization. Pranaya (2014) states that a job hopper is a person who will always change a job and stay at the organization in a short period. Job hopping is the pattern of improving the company and short term working at one organization. According to Mokhtar (2019), job hopping becoming a phenomenon that makes it difficult for organization to hire staff and make staff stay in their organizations. This job hopping had occurred since many years ago which the job hopper felt that it was uncommon to work for the same employer in the long term for their job careers. Therefore, they will be switching jobs at least a few times. With the increasing intensity of global competition and the era of disruption, companies and managers in the service industry are in a stressful or stressed position. Managers are required to be able to make decisions quickly, precisely, and better (Kasmawati, 2018).

In the past, there are rare to see employees who work at the same organization for the long term for their careers. Employers expected and thought that it was unreliable when the job applicants have many working experiences in the short term for one organization. However, nowadays changing the job was like a trend. The employees feel that the unfair organization will decrease the motivation and loyalty that will make them leave the organization (Tolukan \& Akyel, 2019). Job hopping behaviour has been studied in the past year about the management and the rising issues that happen in the organization (Allen, Bryant, \& Vardaman, 2010). Khatri, Fern, and Budhwar (2001) defined job-hopping as the behaviour of employees that change their current job without opportunities for the development in the organization. The factors of employees change a different job because of the impulsiveness, and social influences (Khatri et al., 2001). On the other hands, Ghiselli (1974) explained that job-hopping is a "hobo-syndrome". This "hobo-syndrome" is stated as a periodical "itch" to job hopping. This situation was true which Saleem, et al., (2016) explained that job hopping is common for a person to change the job in particular as a means of quick financial gain, career advancement, or just wanderlust. This desire for fresh experiences where job hopping is a means of creating these fresh experiences.

Besides including the reasons for job hopping in the definition, Settersten and Ray (2010) stated that job hopping as a "work shopping". Employees who change employment are called work shopping with clear reasons. Employees who change jobs frequently were not always restless or fickle. When employees change jobs with a clear objective or success, working in multiple organization is a smart method for them to learn about other workplace cultures, boost their wages, and expand their responsibilities with each shift (Ghazali \& Mokhtar, 2020). 


\section{Reason for Job Hopping}

The intention to change the job can be explained as an attempt of the worker to change to the other organization that fulfils the expectation of employees and there can be a lot of factors that lead towards this intention which the research on it is still running frequently (Saraih, Sakdan, \& Mohd Karim, 2018). In terms of a broad choice of employment, organizational culture, career development, ideal work, gaining more abilities or possibilities, and balancing work-life (Ghazali, Jules \& Othman, 2018), the reasons for work hopping would be expanded. Mohsin, Lengler, and Aguzzoli (2015) claimed that the impacts on job hopping of work safety, income, and organizational loyalty correlate. Meanwhile, Branham (2005) in his book, "The Seven Hidden Reasons Employees Leave" has delineated the several reasons of job hopping; 1) the work environment is not living up to expectations, 2) there is a mismatch between job and person, 3) there is lack of coaching, training, and feedback, 4) there are slow of growth and advancement opportunities, 5) the feeling not valued and unrecognized including pay, 6) stress from overwork and work-life imbalance, 7)loss of trust and confidence in senior leaders.

Moreover, the past researches stated several reasons for employees to job hop for work and because many of them, all factors were categorized into three groups that are private, social, and organizational (Dharmawansha \& Thennakoon, 2014). The authors found that personal factors such as emotional stress, need for better pay, and need for attachment might lead staff to job hop. However, Pranaya (2014) stated that job hopping is the widening opportunities to improve the skills and make a widen choice in the job career. Furthermore, job hopping will be considered as a precursor for the future as it will fully form the career puzzle to be a great person in the career. This is also will help to increase the network and connection of people in the industry.

Islam, Ahmed and Khan (2013) stated that the employee's emotional attachment to the organization is very vital to decrease the employee's job hopping which the relationship amongst intention to change the job and commitment with an organization is said to be negative. However, the employees that have bad behaviour will think that the organization they work for is unfair (İyigün, 2012; Tingül, 2018). As a result, the employees tend to leave the organization and find the other job (Kusci, 2014; Tingül, 2018). They considered that it is not necessarily due to the restlessness of fickleness that individuals who change employment often. Employees who change employment are called work shopping with clear reasons and clear objectives or accomplishment, working in distinct businesses is an intelligent approach for them to comprehend distinct cultures of the office, boost wages and boost their duties with each shift. Whether job hopping is simply described as frequently altering employment, switching to different employment for a distinct purpose, or even renamed as work shopping, it is evident that changing jobs is the key component when defining job hopping commonly or within a brief period (Ghazali \& Mokhtar, 2020).

\section{Employee Job Satisfaction}

Job satisfaction is to describe the job behavior of employees depend on the job and organization. Job satisfaction also subjected to represent the feelings as well as positive 
attitudes towards someone's occupation and can be considered as the affective adaptation with occupation and occupational circumstances (Kohantorabi \& Abolmaali, 2014). Job satisfaction refers to an employee's positive attitude about his or her employment. It can be seen of as a general impression of the job or as a set of attitudes regarding specific components of the employment (Hoboubi et al., 2017).

Additionally, job satisfaction is known as an integral part of knowing the entire life satisfaction and the care of employees (Erro- Garces \& Ferreira, 2019). Therefore, job satisfaction will affect employees' job behavior and job performance. Employee's job satisfaction will help to understand employees' job attitudes and behavior, but at the same time, it also impacts the employees' intentions to stay at the organization (Kim \& Jogaratnam, 2010). As mentioned by Oshagbemi (2003), job satisfaction is a necessary attributes that an organization wants from their employees. Most of the research in this area verified that job satisfaction is a antecedent towards absenteeism, employee turnover, in-role job performance, extra role behaviours and primary antecedents of job attitudes among employee in an organization and also may protect workers from job stress (Hoboubi et al., 2017).

Kim, Leong, and Lee (2005) indicated that job satisfaction is intently allied with the organization commitment and establishment of the organization's competitive advantage. The manager should continuously monitor and evaluate the stage of employees' satisfaction and rewards them for their productivity. Managers should be interested in their employees' job satisfaction in order to indicate their employees' feeling towards their job (Tessema, Ready, \& Embaye, 2013). If the manager concentrates on maximizing employees' job satisfaction, the issues regarding to employees' inability to resolve management conflicts, low morale, increased role conflicts, intergroup tensions, poor overall performance and disciplinary issues may be minimized (Kim et al., 2005).

Furthermore, the job satisfaction of employees is the main concern for operators and managers. This is because job satisfaction will give a result in the positive work performance of employees and this helped to determine the ideal service quality and improve customer satisfaction (Arnett, Laverie, \& McLane, 2002). Norton, Zacher, and Askanasy (2015) stated the job satisfaction was based on the difference between a person's actual rewards and deserved rewards showed the higher satisfaction, while the lower satisfaction appeared on the larger gap. Mokhtar (2019) stated the larger gap would appear the lower satisfaction while the smaller gap would present higher satisfaction. Therefore, employees will show a good commitment when they feel more satisfied in their jobs (Nashuki et al., 2014). It was confirmed that job satisfaction and organizational commitment are positively correlated (Kim, Leong, \& Lee, 2005). This implies that the satisfaction of employees with their jobs will tend to display greater organizational commitment. According to Zainol, Ahmad Rozali, Nordin, Tazijan, \& Ab Rashid (2015), employee dissatisfaction can lead to employee turnover. They claim that dissatisfaction will affect employee commitment and lead them to turnover physically and mentally.

\section{Financial}

Good wages and jobs expectation are vital to a person that always change the job (Ramkumar, 
et al., 2016). Employees must be satisfied with their general wage, as this can affect their attitudes and behaviors. On the other hand, AlBattat et al., (2013) argue that compensation and extrinsic rewards affect employee turnover in the hospitality industry. The connection between economic rewards and employee turnover was also examined by Pohler and Schmidt (2015). They assessed the impacts of managerial pay for performance policies on employee turnover in non-management roles and found that managerial pay for performance strategies could adversely influence employee management relationships were resulting in elevated employee turnover. Pohler and Schmidt's study results endorsed earlier literature claims that pay might impact staff results such as job satisfaction.

There are several studies on talent employees will seek for the high pay. Osibanji et al. (2014) reported that the employees will be good significantly when comes to compensation. Furthermore, financial has been reported in the literature that salary and non-salary benefits bring the employees a vital factor in job hopping. Miller and Wheeler (1992) discovered that the overall financial affects the intention of employees to remain. Employees will able to stay at the organization when the company offers attractive financial to them (Shepherd and Mathews, 2000; Jardine and Amig, 2001). However, the failure of the company to provide the financial as the promise would result in the negative behaviour of employees toward the organization and intention to change the job. Financial at the organizational stage was consider as possible problem in attracting, maintaining, and motivate the employees for the success of the organization (Philips \& Fox, 2003). The purpose being is that financial can influence someone to stay at the organization. Many organizations use the financial to reward and acknowledge the efforts, contributions of employees and also as a motivation instrument (Chiu, Luk, \& Tang, 2002). Moreover, this will enhance the productivity of employees by enhancing job performance, hampering the desire to leave, and increasing job satisfaction. In other words, if an organization fails to provide the staff with equitable compensation, this will lead to adverse behavior on the organization being established and subsequently cause the staff to job hopping.

\section{Perceived Organization Support (POS)}

Perceived organizational support (POS) is documented in the literature is the key predictor of turnover intention (Maertz et al., 2007). Perceived organizational support is the perception of employees on the way of organization value the contribution and cares toward the employees. Therefore, the organization will care about their employees' well-being by rewarding the employees based on job performance and meet their social-emotional needs (Rhoades \& Eiseberger, 2002). The researchers assume that the turnover intention will be decreased when the employees receive positive support from the organization (Sherony \& Green 2002).

POS refers to 'the general perception of employees' where the worker is very particular about the well-being and value of each the employees in the organization. The Social Exchange Theory explained that in return for social rewards, recognition, and material benefits employees are motivated to stay and perform at an organization (Redmond, 2015). The researcher explained that the relationship between the organization and the employees with the provision of support from each other that will provide the benefit for others. However, 
perceived organizational support will make the employees remain in the organization. Moreover, the common context of organizational research suggests there will be an increase in the level of POS when the employees tend to express the good feeling of affiliation and loyalty to stay at the organization (Loi et al., 2006). Perceived organizational support consists that people who monitor their environments and create attributions for the organization's benevolent or malevolent motives and behaviors (Eisenberger et al., 2002). However, the worker will impute the job and regard the favourable or unfavourable treatments that they receive as the indications of whether or not they are favoured or disfavoured by the organization (Rhoades \& Eisenberger, 2002).

\section{Methodology}

This research employed quantitative approach and sample of this study obtained by applying convenience sampling design. The main objective of convenience sampling is to collect information from respondents who were easily accessible to the researchers (Etikan, 2016). There were 231 questionnaires distributed to employees who are currently working in coffee shops such as Starbucks Sdn Bhd, Costa Sdn Bhd, Friendsco Sdn Bhd, and The Coffee Bean \& Tea Leaf Sdn Bhd within Klang Valley area, Malaysia. Klang valley was chosen because it is a strategic location which cover Federal Territory of Kuala Lumpur, Federal Territory of Putrajaya and Selangor District of Petaling and densely populated. In this research, a self-administered questionnaires were distributed to employees who were willing to participate. A proper procedure had been carried out to ensure that the questionnaires were distributed after hours and did not disturb the business operation. After a screening process, a total of 215 questionnaires were valid and proceed to actual data analysis.

\section{Results and Findings}

Based on data obtained, of 215 respondents there were 99 male (46\%) and 116 (54\%) females employees. Majority of the respondents aged between 20 to 29 years old (34.9\%) followed by aged 30 to 39 years old $(31.6 \%)$. Thus, it can be concluded that larger respondents in this study were within young generation. In term of race, majority of respondents were Malays (43.3\%) and followed by Indian (35.3\%) and other races. Majority of the respondents were single and in term of employment status, it can be said respondents who participated in this research were full time employees. The majority of respondents had received formal education, and six of them surprisingly held a PhD qualification. Table 1 below shows the demographic profile of respondents in details.

Table 1. Respondent Demographic Profile

\section{Variables}

Gender

Male

Female

$\underline{\text { Age }}$

Below 20 years

20-29
Frequency

Percentage (\%) 


\section{Macrothink}

40-49

Above 50

$\underline{\text { Race }}$

Malay

Indian

Chinese

Others

Highest educational level

SPM (Malaysian certificate education)

Diploma

Degree

Master

$\mathrm{PhD}$

Marital status

Single

Married

Employment status

Full time

Part time

Others

Period of working in the outlet

Less than 6months

6-12 months

$1-2$ years

2-3 years

more than 3 years

Frequent thinking of job hop

Often

Seldom

Unsure

Working hours in the outlet

6 hours
8 hours
10 hours

International Journal of Human Resource Studies

ISSN 2162-3058 2021, Vol. 11, No. 3

31.6

38
4 $\quad 17.7$

93

43.3

$76 \quad 35.3$

$42 \quad 19.5$

$1 \quad 1.9$

$49 \quad 22.8$

$78 \quad 36.3$

$48 \quad 22.3$

$34 \quad 15.8$

$6 \quad 2.8$

$116 \quad 54$

$99 \quad 46$

$116 \quad 50.2$

$98 \quad 42.4$

10.4

35

16.3

$61 \quad 28.4$

$61 \quad 28.4$

$32 \quad 14.9$

$26 \quad 12.1$

57

26.5

$149 \quad 69.3$

$\begin{array}{ll}9 & 4.2\end{array}$

46

21.4

117

54.4

$52 \quad 24.2$

Subsequently, descriptive analysis was done to analyse the mean score between the variables. Table 2 below shows the descriptive analysis for independent variables and dependent variables. Results of the job satisfaction (mean= 3.5636), financial (mean=3.5622) and perceived organisation support (mean=3.5601) shows similar score which lean towards agreement level. On the other hand, mean score for dependent variable was 2.7289 which fall from disagree to neutral. 
Table 2. Descriptive Analysis of All Variables

\begin{tabular}{lc}
\hline \multicolumn{1}{c}{ Variables } & Mean Score \\
\hline Dependent variables & $\mathbf{2 . 7 2 8 9}$ \\
Job Hopping & \\
Independent variables & $\mathbf{3 . 5 6 3 6}$ \\
Job Satisfaction & $\mathbf{3 . 5 6 2 2}$ \\
Financial & $\mathbf{3 . 5 6 0 1}$ \\
Perceived Organization Support & \\
\hline
\end{tabular}

Note: $\quad 1=$ strongly disagree, $2=$ disagree, $3=$ neutral, $4=$ agree, $5=$ strongly agree

Additionally, Pearson's Correlation analysis was used to determine the strength and relationship of the job satisfaction, financial and perceived organization support towards the job hopping behaviour among employees in coffee shops. Based on the result obtained, it showed that all variables found to be weak correlated with value range from 0.0 to 0.2 . Financial found to be weak negatively correlated $\mathrm{r}=-0.122, \mathrm{p}=0.074$. Perceived organization support had negative relationship with $\mathrm{r}=-0.097, \mathrm{p}=0.155$ and job satisfaction correlated with $\mathrm{r}=-0.130, \mathrm{p}=0.056$. One plausible explanation for this could be that employees working in coffee shops industry in Klang valley area received a good salary and good support from their supervisors. Therefore this lead to high job satisfaction. In other word, it can be said that the higher the job satisfaction the lower the job hopping (Jules et al., 2017). Table 3 shows the result in details.

Table 3. The Pearson Correlation Analysis between variables and Job Hopping Behavior

\begin{tabular}{|c|c|c|c|c|c|}
\hline & & JHB & FINANCIAL & POS & JS \\
\hline \multirow[t]{3}{*}{ JHB } & Pearson Correlation & 1 & -.122 & -.097 & -.130 \\
\hline & Sig. (2-tailed) & & .074 & .155 & .056 \\
\hline & $\mathrm{N}$ & 215 & 215 & 215 & 215 \\
\hline \multirow[t]{3}{*}{ FINANCIAL } & Pearson Correlation & -.122 & 1 & $.941^{* *}$ & $.985^{* *}$ \\
\hline & Sig. (2-tailed) & .074 & & .000 & .000 \\
\hline & $\mathrm{N}$ & 215 & 215 & 215 & 215 \\
\hline \multirow[t]{3}{*}{ POS } & Pearson Correlation & -.097 & $.941^{* *}$ & 1 & $.978^{* *}$ \\
\hline & Sig. (2-tailed) & .155 & .000 & & .000 \\
\hline & $\mathrm{N}$ & 215 & 215 & 215 & 215 \\
\hline \multirow[t]{4}{*}{ JS } & Pearson Correlation & -.130 & $.985^{* *}$ & .97 & 1 \\
\hline & & & & $8^{* *}$ & \\
\hline & Sig. (2-tailed) & .056 & .000 & .000 & \\
\hline & $\mathrm{N}$ & 215 & 215 & 215 & 215 \\
\hline
\end{tabular}

**. Correlation is significant at the 0.01 level (2-tailed).

Furthermore, in order to predict factors influence job hopping behaviour among employees, 
the Multiple Linear Regression was done. Table 4 below represents the multiple linear regression data analysis between dependent variable and independent variables of this study. Based on table 4 below surprisingly only $6.9 \%$ of variance in coffee shops' employees was explained by job satisfaction, financial and perceived organization support. It means that other $93.1 \%$ was explained and predicted by other factors. This result suggest those three variables were not the best influence or indicator on employees' job hopping behaviour. One possible managerial implication from this is that the employees' did not think that these variables influenced their thinking to job hop from their current work because they are satisfied with their current job, salary and also perceived good support from supervisors. Frequencies result in table 1 supported this findings with majority of employees seldom thought of job hopping with 69.3 percent and only 26.5 percent employees often thought of job hop. These findings are reasonable enough to propose that employees who experience high levels of satisfaction are less likely to job hop and leave the company. This findings parallel to the previous studies on factors impacts the employees' intentions to stay at the organization (Kim \& Jogaratnam, 2010; Nashuki et al., 2014; Nasir et al., 2019; Sherony \& Green 2002).

Table 4. Model Summary

\begin{tabular}{lllll}
\hline & & & & Std. Error of the \\
Model & $\mathrm{R}$ & R Square & Adjusted R Square & Estimate \\
\hline 1 & $.262^{\mathrm{a}}$ & .069 & .055 & .64511 \\
\hline
\end{tabular}

A. Predictors: (Constant), Js, Pos, Financial

\section{Conclusion}

This research has fulfilled the objective of study on investigating possible factors that influence job hopping behavior among coffee shops employees. Three variables were used that are job satisfaction, financial, and perceived organizational support. This research has some notable strength. Firstly, even though findings from this research found that these three factors did not directly influenced coffee shops employees to job hop but the findings might shape some direction and alert the coffee shop operators on importance of these three variables in the coffee shop industry in order to minimize employees thinking of job hopping. These three variable found to be negatively weak correlated towards turnover intention and Multiple regression analysis also predicted only $6.9 \%$ of variance in coffee shops' employees was explained by job satisfaction, financial and perceived organization support $\left(\mathrm{R}^{2}=.069\right)$. Finding of this research found parallel with previous studies which stated the employees will show a good commitment and less intention to job hop when they feel more satisfied in their jobs (Nashuki et al, 2014; Kim, Leong, \& Lee, 2005). This implies that the coffee shop employees that participated in this research satisfied with their current jobs, salary and subsequently display greater organizational commitment. It is agreed that if the coffee shops employees dissatisfied, it can lead to employee turnover (Zainol et al., 2015). Furthermore, it is well accepted that dissatisfaction will affect employee commitment and lead them to turnover. Employees are more committed and likely to stay with the organization if they feel 
that the organization acted positively towards them and less likely to remain with the organization if they do not feel the positive act of the organization.

Generally, job hopping behavior is always related to financial, monetary and benefits. Employees were looking for an organization that could pay them better and provide attractive benefits. Salary also play an important roles to attract employees to stay working in the organization. Employees will able to stay at the organization when the company offers attractive financial to them (Ramkumar, et al., 2016; Shepher and Mathews, 2000; Jardine and Amig, 2001). Employees will quit the job when there is a great opportunity from the other organization with better benefits which will give job satisfaction to the employee. However, the failure of the company to provide the financial as the promise would result in the negative behaviour of employees toward the organization and intention to change the job. Support from supervisor also play role to retain employees working at current workplace (Ghazali, Nashuki, \& Othman, 2018).

On the other hand, this research is very useful in highlighting the need for the organization to retain these variable and maybe to improve current strategies to make sure employees stay working with them and less thinking to job hop. For examples, employees working at Starbucks were received attractive package which inclusion of perks, partner card and life assurance (Starbucks website, 2020). Additionally, Starbucks' success attributed to a strong interaction between employees and customers, a culture of diversity and inclusiveness, and assistance and support for employees to grow and learn (Goh et al., 2020).

Future researchers could highlight current practice in the coffee shops which able to retain their employees to stay working with them. Through this research, the management can explore and understand further about the factor affecting the job-hopping behavior among employees in the coffee shops. Additionally, findings obtained from this research, may help the managers or coffee shop operators to create awareness of the possible factors that may lead to the job-hopping of their employees. This is important to ensure that the employees able to perform well as the performance of employees will picturize the productivity of the overall operation of an organization. Once the major understanding is corrected, this coffee shop able to retain employees and ultimately reduce turnover intention.

Lastly, the other perspective gathered from findings of this research was about to understand the loss of skilled employees could give a negative effect on the service quality, which could cause financial distress to organizations. The organization may face some problem to provide great quality services to its customers. Then, it is hoped this research may help the managerial level to provide a proper and good strategy for staff retaining as the job-hopping may lead to the high turnover of the employees in the industry. Once this scenario happened, it will reflect and picturized on how the organization of the industry manages its employees.

\section{Recommendation and Implication}

The researchers hope that this research will serve as a foundation for further research on job hopping behavior and turnover intention in the coffee shop context, as there are numerous additional areas of study that would be interesting to investigate further. Following that, future research should look at other plausible variables that could explain the 
issue identified in this research perhaps filling the research gap and investigate other variables that might lead to turnover intention. It is recommended in the future to employ qualitative method in conducting research in this field. By using qualitative design, it is expected other factors or perspective can be obtained and surprising finding also can be revealed. Besides, mixed method combining qualitative and quantitative also can be used as it will result in diverse finding and provide more rich data. Lastly, future research also might consider to wider location and larger sample size to obtain good data representation and generalization.

\section{References}

Arnett, D., \& Mclane, L. (2002). Using Job Satisfaction and Pride as Internal Marketing Tools. Cornell Hotel and Restaurant Administration Quarterly, 43(2), 87

AlBattat, A. R. S., \& Som, A. P. M. (2013). Satisfaction And Turnover Crisis In Malaysia's Hospitality Industry. Pg 260-266. Proceedings of International Conference on Tourism Development, February 2013.

Allen, D. G., Bryant, P. C., \& Vardaman, J. M. (2010). Retaining talent: replacing misconceptions with evidence-based strategies. Academy of Management Perspectives, 24(2), 48-64. https://doi.org/10.5465/amp.24.2.48

Branham, L. (2005). The 7 Hidden Reasons Employees Leave: How to Recognize the Subtle Signs and Act Before It's Too Late. Library of Congress Cataloguing-in Publication Data, United States of America.

Chiu, R. K., Luk, V. W. M., \& Tang, T. L. P. (2002). Retaining and Motivating Employees: Compensation Preferences in Hong Kong and China. Personnel Review, 31(4), 402-431.

Dharmawansha, P. I. \& Thennakoon, D. (2014). An Exploratory Study on Job Hopping in Sri Lanka: A study on generation "Y" employees. In IRCMF 2014: $9^{\text {th }}$ International Research Conference on Management and Finance, 19 December 2014, Colombo, Sri Lanka. (Unpublished) employee intention to stay: Do human resource management practices matter.

Eisenberger, R., Stringlhamber, F., Vandenberghe, C., Sucharski, I., \& Rhoades, L. (2002). 'Perceived organisational support: Contributions to perceived organisational support and employee retention'. Journal of Applied Psychology, 87, 565-573. https://doi.org/10.1037/0021-9010.87.3.565

Etikan, I. (2016). Comparison of Convenience Sampling and Purposive. American Journal of Theoretical and Applied Statistics, 5(1), 1-4.

Erro, A., \& Ferreira, S. (2019). Do Better Workplace Environmental Conditions improve Job Satisfaction? Journal of Cleaner Production.

Falkenburg, K., \& Schyns, B. (2007).Work satisfaction, organizational commitment and withdrawal behaviours". Management Research News, 30(10), 708-723. https://doi.org/10.1108/01409170710823430 
Ghazali, H., \& Roslan, N. N. (2020). Investigating On Job Hopping Behavior Among Restaurant Employees In Malaysia. International Journal of Asian Social Science, 10(11), 706-714.

Ghazali, H, Jules, N. J., \& Othman, M. (2018). Examining the Influence of Perceived Organizational Support towardsJob-Hopping Behaviour: A Case of Casual Dining Restaurant Employees' in Klang Valley Area, Malaysia. International Journal of Accounting, Finance and Business (IJAFB), 3(12), 101-108.

Ghazali, H., \& Mokhtar, K. (2020). Exploring Job Hopping Behavior among Managers of Casual Dining Restaurants In Klang Valley Area, Malaysia. International Journal of Management and Applied Science, 6(6), 80-82

Ghazali, H., Nashuki, N. M., \& Othman, M. (2018). The Influence of Perceived Organizational Support (POS), Perceived Supervisory Support (PSS) and Organizational Commitment (OC) towards Intention to Leave or Intention to Stay: A case of Casual Dining Restaurants in Klang Valley, Malaysia. International Journal of Academic Research in Business and Social Sciences, 8(9), 1884-1902.

Ghiselli, E. E. (1974). Some perspectives for industrial psychology. American Psychologist, 29(2), 80-87

Goh, S. Y., Kee, D. M., Ooi, Q. E., Boo, J. J., Chen, P. Y., Alosaimi, \& Ghansal, M. (2020). Organizational Culture at Starbucks. Journal of the Community Development Asia. Page 1-7

Human Resource Online (2018). Retrieved from https://www.humanresourcesonline.net/live-hr-vendors-of-the-year-2018-malaysia

Hussain, T., \& Asif, S. (2012). Is employees' turnover intention driven by organisational commitment and perceived organisational support? Journal of Quality and Technology Management, 8(11), 1-10.

Hoboubi, N., Choobineh, A., Kamari, Ghanavati, F., Keshavarzi, S., \& Akbar Hosseini, A. (2017). The Impact of Job Stress and Job Satisfaction on Workforce Productivity in an Iranian Petrochemical Industry. Safety and Health at Work, 8(1), 67-71.

Ibrahim, A. M. (2019). Drivers of organizational commitment and job satisfaction among lodging industry employees. Journal of Tourism, Hospitality \& Culinary Arts, 11(2), 1-19.

Islam, T., Khan, S. U. R., Ahmad, U. N. U., Ali, G., Ahmed, I., \& Bowra, Z. A. (2013). 'Turnover intentions: The role of perceived organizational support and organizational commitment'. Procedia Social and Behaviour Sciences, 103, 1237-1241. https://doi.org/10.1016/j.sbspro.2013.10.452

İyigün, N. Ö. (2012). Organizational justice: A theoritical approach. Ístanbul Ticaret University Journal of Social Sciences, 11(21), 49-64.

Jardine, E., \& Amig, S. (2001). Managing Human Capital. Behavioral Health Management, 21(2), 22-26. 
Jules, N. J., Ghazali, H., \& Othman, M. (2017). Job satisfaction and job hopping behaviour among employees of casual dining restaurant. Journal of Tourism, Hospitality \& Culinary Arts, 9(2), 1-12.

Kasmawati (2018). Sumber Manusia Sebagai Sumber Keunggulan Kompetitif. Journal Idaarah, 11(2), 1-24.

Khatri, N., Fern, C. T., \& Budhwar, P. (2001). Explaining employee turnover in an Asian context. Human Resource Management Journal, 11(1), 54-74.

Kim, W. G, Leong, J. L., \& Lee, Yong-Ki. (2005). Effect of service orientation on job satisfaction, organizational commitment, and intention of leaving in a casual dining chain restaurant. International Journal of Hospitality Management, 24(2), 171-193.

Kim, K., \& Jogaratnam, G. (2010). Effects of Individual and Organizational Factors on Job Satisfaction and Intent to Stay in the Hotel and Restaurant Industry. Journal of Human Resources in Hospitality \& Tourism, 9(3), 318-339.

Koh, H. C., \& Goh, C. T. (1995). An analysis of the factors affecting the turnover intention of non-managerial clerical staff: A Singapore study. The International Journal of Human Resource Management, 6(1).

Kohantorabi, F., \& Abolmaali, K. (2014). The Prediction of Job Satisfaction Based on Coping Skills in Pilots and Assistant of Pilots. Journal of Service Science and Management, 07(03), 260-266. https://doi.org/10.4236/jssm.2014.73023

Kuşci, E. (2014). Perceptions of organizational justice academics in universities (Yüzüncü Y1l University example), Master's Thesis, Yüzüncü Yıl University Institute of Educational Sciences, Van.

Lim, C. Y. (2013). Singapore's National Wages Council: An Insider's View. World Scientific.

Loi, R., Hang-Yue, N., \& Foley, S. (2006). Linking employees' justice perceptions to organizational commitment and intention to leave: The mediating role of perceived organizational support. Journal of Occupational and Organizational Psychology, 79(1), 101-120.

Maertz, C. P., Griffeth, R. W., Campbell, N. S., \& Allen, D. G. (2007). The effects of perceived organizational support and perceived supervisor support on employee turnover", Journal of Organizational Behavior, 28, 1059-1075.

Jawaad, M., Amir, A., Bashir, A., \& Hasan, T. (2019). Human resource practices and organizational commitment: The mediating role of job satisfaction in emerging economy. Cogent Business \& Management.

Miller, J. G., \& Wheeler, K. G. (1992). Unraveling the Mysteries of Gender Differences in Intentions to Leave the Organization. Journal of Organizational Behaviour, 13(5), 465-478. 
Miller, P. E. (2007). The relationship between job satisfaction and intention to leave: A study of hospice nurses in a for-profit Corporation. Ph.D., Capella University, Ann Arbor. ProQuest, UMI Dissertations Publisekencihing.

Mohsin, A., Lengler, J., \& Aguzzoli, R. (2015). Staff turnover in hotels: Exploring the quadratic and linear relationships. Tourism Management, 51, 35-48.

Mokhtar, K. (2019). Exploring Job Hopping Behaviour Among Managerials in Casual Dining Restaurant in Klang Valley. Degree thesis. Universiti Putra Malaysia.

Nasyira, M. N., Othman, M., \& Ghazali, H. (2014). Predictors of intention to stay for employees of casual dining restaurant in Klang Valley area. International Food Research Journal, 21(3), 863-871.

Nasir, N. N. M., \& Ghazali, H. (2019). Predictors of Intention to Leave a Job for Employees of Casual Dining Restaurant in Klang Valley, Malaysia. International Journal of Academic Research in Business and Social Sciences, 9(5), 773-783.

Norton, T. A., Zacher, S. L. P., \& Neal, M. A. (2015). Employee Green Behavior: A Theoretical Framework, Multilevel Review, and Future Research Agenda. Organization \& Environment, 28(1), $103-125$.

Osibanjo, O. A., Adeniji, A. A., Falola, H. O., \& Heirsmac, P. T. (2014). Compensation Packages: A Strategic Tool for Employees' Performance and Retention. Leonardo Journal of Sciences, 25, 65-84.

Oshagbemi, T. (2003). Personal correlates of job satisfaction: Empirical evidence from UK universities. International Journal of Social Economics, 30(11-12), 1210-1232. https://doi.org/10.1108/03068290310500634

Philips, L., \& Fox, M. A. (2003). Compensation Strategy in Transnational Corporations, Management Decision, 41(5), 465-476.

Pallant, J. (2010). SPSS survival manual: A step by step guide to data analysis using SPSS (4th edn.). London: McGraw-Hill.

Pranaya, D. (2014). Job-Hopping-An Analytical Review. International Journal of Research in Business Management (IMPACT: IJRBM) ISSN (E), 2(4), 67-72.

Prasada, P. P. B., \& Sawitri, N. N. (2019). Prediction of Work Stress, Leadership Quality, Motivation of work and Organization Culture to Work Satisafaction and Impact on Turnover Intention Employees. Jurnal Manajemen dan Pemasaran Jasa, 12(2), 269-280.

Pohler, D., \& Schmidt, J. A. (2015). Does pay-for-performance strain the employment relationship? The effect of manager bonus eligibility on non-management employee turnover. Personnel Psychology, 68(2), 1-35.

Ramkumar, A., kumar, A., Kumar, S., Hazarika, S., Radhika, S., \& Shravanthi, V. K. (2016). A study on the factors affecting job hopping behaviour of its employees. International Education and Research Journal, 2(6), 97-99. 
Redmond, Mark V., "Social Exchange Theory" (2015). English Technical Reports and White Papers. 5. https://lib.dr.iastate.edu/engl_reports/5

Rhoades, L., \& Eisenberger, R. (2002). Perceived organisational support: A review of literature. Journal of Applied Psychology, 87(4), 698-714. https://doi.org/10.1037/0021-9010.87.4.698

Saleem, T., Saleem, S., \& Jalil, A. (2016). Unweaving Hobo syndrome in Banking, Health and Development sector. Gomal J Med Sci., 12, 227-32.

Saraih,U. N., Sakdan, M. F., Mohd, K. K. (2018). The Relationships between Interpersonal Communication, Task Design and Job Performance: A Case of Employees in the Manufacturing Company

Sekaran, U. (2005). Research Methods For Business: A Skill Building Approach (4 ed.). New York, NY: John Wiley \& Sons, Inc.

Sherony, K. M., \& Green, S. G. (2002). Coworker exchange: Relationships between coworkers, leader-member exchange, and work attitudes. Journal of Applied Psychology, $87(3), 542-548$.

Settersten, R., \& Ray, B. E. (2010). Not quite adults: Why 20-somethings are choosing a slower path to adulthood, and why it is good for everyone.

Shepherd, J. L., \& Matthews, B. P. (2000) Employee Commitment: Academic vs Practitioner Perspectives. Employee Relations, 22(6), 555-575.

$\begin{array}{llll}\text { Starbucks } & \text { official } & \text { Rebsite. } & \text { Retrieved }\end{array}$ https://www.starbucks.com/aboutus/company-information.

Starbucks (2020). Culture and Values. Retrieved from https://www.starbucks.com/careers/working-at-starbucks/culture-and-values

Tessema, M. T., Ready, K. J., \& Embaye, A. B. (2013). The Effects of Employee Recognition, Pay, and Benefits on Job Satisfaction: Cross Country Evidence. Journal of Business and Economics, 4(1), 1-12.

Tolukan, E., \& Akyel, Y. (2019) Research on the Relationship between Trainers' Turnover Intention and Organizational Justice. International Journal of Higher Education, 8(1). https://doi.org/10.5430/ijhe.v8n1p181

Tingül, S. D. (2018). The effect of organizational justice perception on employees' leaving behaviours. Master's Thesis, Bahçeşehir University, Institute of Social Sciences. İstanbul.

Weiss, H. M. (2002). 'Deconstructing job satisfaction: Separating evaluations, beliefs and affective experiences', Human Resource Management Review, 12(2), 173-194.

Zainol, N., Ahmad Rozali, A., Nordin, N., Tazijan, F., \& Ab Rashid, P. (2015). Employees Dissastification and Turnover Crises: A Study of Hotel Industry, Malaysia. https://doi.org/10.2139/ssrn.2576603 


\section{Copyright Disclaimer}

Copyright for this article is retained by the author(s), with first publication rights granted to the journal.

This is an open-access article distributed under the terms and conditions of the Creative Commons Attribution license (http://creativecommons.org/licenses/by/4.0/). 